\title{
Studia Poradoznawcze. Journal of Counsellogy 2012, Wydawnictwo Naukowe Dolnośląskiej Szkoły Wyższej, Wrocław 2012
}

Ukazanie się nowego czasopisma i to na poziomie międzynarodowym należy powitać specjalnie. Jest to pismo, które powstało na bazie długoletniej pracy i starań środowiska naukowego tworzonego przez prof. dr hab. Alicję Kargulową, która konsekwentnie od trzydziestu przeszło lat organizuje konferencje naukowe, prowadzi seminaria doktorskie, pisze podręczniki, promuje termin poradoznawstwo. I tak w latach 1979 - 95 odbywały się regularnie konferencje, najczęściej w Karpaczu na temat poradnictwa. Po każdej konferencji ukazywał się zbiór referatów i dyskusji. Wiele osób - uczestników tych konferencji już nie żyje. Należy do nich prof. M. Kulczycki, pracownik Wrocławskiego Instytutu Psychologii czy prof. Wanda Rachalska, organizatorka poradnictwa zawodowego, prof. M. Trawińska zajmująca się poradnictwem rodzinnym i inni.

Konferencje w Karpaczu były przestrzenią dyskusji nad poradnictwem i powstaniem nauki, która badała tę dziedzinę działań społecznych.

Powstała nazwa nowej dyscypliny - poradoznawstwo - tak jak kulturoznawstwo. W 2011 roku powołano Naukowe Towarzystwo Poradoznawstwa, które zainicjowało powstanie European Society for Vocational Designing and Career Conseling w Padwie 10.IX.2011 roku, do tego międzynarodowego gremium adresowane jest dwujęzyczne pismo polsko-angielskie, którego nazwa wywodzi się z jęz. angielskiego consel - porada, logy - teoria.

Jeśli piszę recenzję to kieruję się następującymi racjami:

Uczestniczyłam we wszystkich konferencjach i wygłaszałam na nich referaty. Uczestniczyłam w dyskusjach. Zajmowałam się problematyką poradnictwa $\mathrm{w}$ wielu aspektach. W aspekcie historycznym badałam poradnictwo 
prowadzone przez Towarzystwo Przyjaciół Dzieci, tworzone na bazie koncepcji pedagogiki społecznej - melioracji środowiska społecznego oraz szkoły jako instytucji edukacyjnej i lokalnej. Porada społeczno-wychowawcza miała być otwarta na potrzeby uczniów, nauczycieli i rodziców. Zajmowałam się poradnictwem, jak je nazwałam pośrednio prowadzonym na łamach czasopism - głównie „Twojego Dziecka”, ale i pism kobiecych jak: „Przyjaciółka”, „Twój Styl”, „Kobieta i Życie” czy „Zwierciadło”. Do takiego poradnictwa zaliczyłam poradnictwo przez telefon w Polsce i we Francji. Nastawione na pomoc młodzieży, dzieciom i ludziom starszym. Badałam także poradnictwo kulturalno-oświatowe dotyczące instytucji społecznych i stylu życia: jedzenia, urządzania domu itd.

Drugą przesłanką pisania recenzji jest kontakt z autorkami artykułów, wydrukowanymi w piśmie. Prawie wszystkich autorów znam z konferencji i ich prac, które recenzowałam jako recenzent wydawniczy czy recenzent prac na stopień.

Pismo zawiera następujące działy:

Dział I - Studia i rozprawy - nastawiony na rozprawy teoretyczne, problemy badawcze, kierunki działań.

Dział II - Komunikaty z Badań.

Dział III - Rekomendacje dla praktyk poradnictwa.

Dział IV - Aktualności i kronika.

Pismo jest bardzo starannie zredagowane i zawiera odkrywczy ogląd poradnictwa. Uzyskane zostały jego nowe pola działania, jak i formy. Poradnictwo przekształciło się pod wpływem przemian ponowoczesnego społeczeństwa. Bieg tych przemian i jego ramy, wymiar i drogi przedstawia A. Kargulowa w pierwszym artykule, który ze względu na Autorkę, która jest redaktorem naczelnym pisma, jego główną inicjatorką, jak i kreatorką środowiska naukowego poradoznawstawa - dlatego artykuł ten wymaga szczegółowego omówienia. Obecne poradnictwo określone zostało jako poradnictwo ery komunikacji satelitarnej.

Poradnictwo, choć zawsze będzie działaniem odbywającym się w bezpośrednim kontakcie między osobami, to kontakt ten ma miejsce w określonym czasie i przestrzeni społecznej, a przestrzeń życia społecznego ulega zmianom. Na zmiany te i ich wpływ na poradnictwo zwraca uwagę A. Kargulowa. Analizuje zmiany jakie dokonały się w poradnictwie od okresu ery telegrafu, radia i telewizji a postindustrialnym społeczeństwem sieci społeczeństwem ery komunikacji satelitarnej. Jakie trudności przeżywa człowiek żyjący w kręgu kultury „natychmiast”, „szybko”, „od razu”, zaopatrzony $\mathrm{w}$ telefon komórkowy, komputer i internet? Ściągający do swego domu, po- 
koju informacje z odległych zakątków świata, robiący znajomości, rozmowy na Skypie. Dyskusje w internecie pozwalają na natychmiastowy kontakt, ale ten kontakt nie jest bezpośredni choć twarzą w twarz. Czy można mówić tu o empatii, o więzi uczuciowej? Jeśli tak to powstaje nowe odczuwanie braku ciepła, bliskości, kontaktu rzeczywistego bez pośrednictwa techniki i urządzeń. Może brak nam ciepła, zapachu, oddechu, nawet gdy może on wywołać odrazę, niechęć, przykrość. Czasami negatywne uczucia są nam potrzebne, aby je pokonać, przezwyciężyć, przemóc się. Władanie sobą, reagowanie na swoje zachowania, przezwyciężanie niechęci buduje nas i wzmacnia. Przemiany społeczne wpływają na poradnictwo $\mathrm{w}$ jego wyspecjalizowanych formach, kierunkach.

Słusznym jest umieszczenie na drugim miejscu artykułu B. Wojtasik, specjalistki w zakresie poradnictwa zawodowego. Zmiany jakie dokonały się w społeczeństwie w bolesny sposób, dotknęły system pracy zawodowej. Zaniknął lub zanika model kariery zawodowej na całe życie, długiego stażu pracy w jednym zawodzie, w jednym miejscu, w jednym zakładzie. Powstała konieczność doskonalenia się i stałego dokształcenia w swoim zawodzie, powstała często konieczność zmiany zawodu w trakcie życia. Zmiany miejsca pracy. Trzeba się przekwalifikować, przestawić na nowe zadania, nowe czynności. Trzeba umieć się uczyć, nawet w wieku 50+. Życie staje się płynne, pokawałkowane na trochę tu i trochę tam, trochę w biegu, trochę wśród swoich i trochę wśród obcych. Przygotować do zmiany mają biura kariery zawodowej, poradnie zawodowe dla bezrobotnych, bezradnych osób, które utraciły swój zawód i dawny zakład pracy. Nie byliśmy w Polsce przygotowani do pracy z bezrobotnymi, do uczenia nowych zawodów w trakcie życia.

Przygotowanie doradców w poradnictwie zawodowym do nowych zadań i nowych sytuacji to konieczność wynikająca z przemian społecznych. W trakcie tych działań występuje nurt poradnictwa biograficznego propagowanego przez Alheita. Pojawia się doradca kariery życiowej, biograficznej. Poszukuje się rozwiązań między sztywnym systemem a elastyczną zmianą (s. 39). Każdy powinien próbować być otwartym na innych. Poradnictwo zawodowe staje się działaniem i jednocześnie jest usługą (s. 43). Konieczne jest budzenie i kształtowanie refleksyjności, postawy poszukiwania swego miejsca w zmieniającym się świecie.

Kolejny artykuł Anety Słowik dotyczy trudnej sytuacji emigracji. Życiu na emigracji towarzyszy uczucie „zawieszenia” - floating - i zabłąkania. Zjawiska te badała A. Bron, która sama przeżyła takie stany, emigrowała bowiem z Polski w okresie PRL ze środowiska sympatyzującego z ówczesną władzą. Jej ojciec należał do profesorów promujących socjalizm i walczących 
z wrogą ideologią, do których zaliczał między innymi pedagogikę społeczną. Idealizował wszystko co radzieckie, postępowe, socjalistyczne. Jak reagowała na Zachód i demokratyczne społeczeństwo? Czy jej zawieszenie było trudniejsze, nie wiem, przezwyciężyła je i zakorzeniła się w zachodnim społeczeństwie pozytywnie, zdobyła pozycję.

Autorka artykułu bada polską emigrację na Zachód i wyróżnia kilka jej etapów. Każdy etap tworzy inne potrzeby pomocy, inne drogi wrastania i zakorzenienia się w świecie.

A. Słowik analizuje poszczególne etapy życia w zawieszeniu i sposoby pomocy wyjścia z tych stanów, dojścia do sytuacji uczenia się życia w nowych warunkach, w nowej kulturze. Za P. Jarvisem to uczenie się jest uczenie się egzystencjalnym, byciem dorosłym na emigracji poszukującym swego miejsca w nowych środowiskach, bycie autonomicznym, samodzielnym. Poradnictwo służące emigrantom powinno służyć pomocą, wyjściem ze stanu zawieszenia, zabłąkania, zagubienia i doprowadzić do odnalezienia siebie w nowej sytuacji, bycia sobą w innej kulturze, wśród obcych, ale coraz bliższych ludzi.

Kolejny artykuł Ewy Trębińskiej-Szumigraj koncentruje się na problematyce osób uwikłanych w życie osób uzależnionych. Autorka badała sytuację matek synów narkotyzujących się i analizowała stany matek, które chciały pomóc synom wyjść z nałogu i osiągnąć niezależność i samodzielność. Ne mogły odrzucić synów, wchodziły w stan uzależnienia od nich i ich nałogu, droga od uzależnienia do wyzwolenia i samodzielności była trudna i wymagała pomocy.

Zasadny jest artykuł dwóch autorów: A. Bilon i J. Kargula - Społeczno-kulturowe konteksty definiowania roli doradcy. Autorzy przytaczają i analizują różne badania dotyczące roli doradcy. Doradca towarzyszy radzącemu się $\mathrm{w}$ procesie szeroko rozumianym konstruowaniem porady i biografii radzącego się. Od tego jak jest postrzegany to towarzyszenie może być incydentalne lub długotrwałe, ważne i nieistotne. Istotny też jest sposób udzielania porad oraz płeć doradcy.

Specjalne uwagi wywołał artykuł Darii Zielińskiej-Pękał pt. Od pomocy do przemocy w poradnictwie, dwie narracje.

Pierwsza uwaga, która się mi nasuwa to postawa badacza, który zajmuje się jakimś zagadnieniem. Zagadnienie owo kieruje jego uwagę na wszystko, co może się z nim łączyć, pośrednio i bezpośrednio. Badacz zaczyna postrzegać świat i rzeczywistość przez pryzmat owego zagadnienia. Tak jest z Autorką. Jej koncentracja na poradnictwie rzutuje na jej sposób patrzenia i analizowania kreskówki - bajki dla dzieci w telewizji opartej o opowieści 
o Kubusiu Puchatku. Dzień Osiołka to sytuacja, w której zwierzątka starają się uszczęśliwić Osiołka, który wydał się im smutny. Przyjaciele obserwują Osiołka i podejmują decyzję (diagnozę), że trzeba mu pomóc. Każdy z przyjaciół - sowa, królik, proponują rzeczy, które ich uszczęśliwiają jak: warzywa, latanie itp. Jest to karykatura poradnictwa, które oferuje rozwiązania dobre z punktu widzenia osoby radzącej a nie radzącej się.

Druga część artykułu analizuje blogi doradcze w Internecie. Jest to nowa forma poradnictwa, która powstała, gdy pojawił się i upowszechnił Internet.

Ostatni dział czasopisma zawiera komunikaty z badań. Pierwszy J. Dec dotyczy poradnictwa dla osób z grup marginalizowanych - street-workingu - poradnictwo to obejmuje dzieci ulicy, bezdomnych, prostytutki i uzależnionych. Jest liberalne i dialogowe. Artykuł zawiera konkretne wskazania instytucji, które zajmują się pomocą.

Kolejne dwa artykuły dotyczą problemów - poradnictwa w procesie adopcji. Pisze na ten temat A. Ładyżyński, słusznie stwierdza, że nie może określić tego poradnictwa jako dyrektywne, liberalne czy krótkotrwałe, przygotowawcze, prowadzące, dotyczące tylko rodziców czy tylko dziecka. Poradnictwo służy pomocą w fazie przygotowawczej, fazie aklimatyzacji, w fazie trwania adopcji jeśli taka potrzeba się pojawia. Dziś dobiera się raczej rodzinę do dziecka, niż dziecko do rodziny. Doradcy zachowali swój charakter osób rozstrzygających i decydujących. Rodzina adopcyjna zmienia się. Mogą pojawić się w niej dzieci rodziców adopcyjnych, mogą dojść jeszcze inne dzieci z adopcji. Dzieci adoptowane rosną, dojrzewają, rozwijają się.

Wreszcie czwarty dział zawiera recenzje:

Pierwsza recenzja to prezentacja pracy E. Siarkiewicz pt. Przesłonięte obszary poradnictwa. Realia, iluzja, ambiwalencja. Pracę tą czytałam w maszynopisie i pisałam jej recenzję wydawniczą. Byłam pozytywnie zaskoczona sposobem opisu poradnictwa, jego szczegółowej kompetencji analizy. Autorka widzi wszystko od wejścia do poradni, do pokoju doradcy przez informacje, sposób uzgodnienia wizyty - zaproszenia przez sam proces porady, pomocy. Nie waha się pisać o ambiwalencjach, trudnościach, wahaniach doradcy i radzącego się. Z książki można się dowiedzieć o realiach, iluzjach poradnictwa i poznać wymiary ambiwalencji poradnictwa.

Kolejne dwie pozycje dotyczą poradnictwa w sytuacji chorych na raka, w tym kobiet chorych na raka piersi. Szczegółowo omówiony został ruch wspierających leczenie raka piersi w Stanach Zjednoczonych.

Recenzowany numer nowego czasopisma jest bardzo starannie zredagowany. Ukazuje szeroki zakres poradnictwa jako pomocy, wspierania, usa- 
modzielnienia osoby żyjącej w trudnej sytuacji, poddanej presji przemian społecznych i kulturowych. Należy podkreślić, że każdy artykuł cechuje bardzo dobry warsztat naukowy, literatura z szeroko zarysowanych nauk społecznych i ogólnie humanistyki. Poradoznawstwo rozwija się we wrocławskim ośrodku promieniującym na inne uczelnie i instytucje zajmujące się poradnictwem zadziwiająco.

Takiego rozwoju należy życzyć andragogice i gerontologii, dyscyplinom bliskim mi tak, jak kiedyś bliskim było mi poradnictwo. Sam termin poradoznawstwo nadal mnie „kłuje”, ale nie mam na to wpływu i przyjęłam go ze zrozumieniem intencji Twórczyni terminu. Pismo powinno znaleźć się w poradniach, biurach karier na Wyższych Uczelniach, na których jest pedagogika.

Olga Czerniawska 